\title{
Evaluation of the Bioactivity of Water Extracts from Dicotyledonous Crops on Model Weeds and Pathogens
}

\section{Valenzuela Averruz, Leticia Estereniel}

2018-07

Valenzuela Averruz , L E , Zou , L , Santanen , A A \& Mäkelä , P S A 2018 , ' Evaluation of the Bioactivity of Water Extracts from Dicotyledonous Crops on Model Weeds and Pathogens ' , Journal of agriculture food and development , vol. 4 , pp. 17-22 . https://doi.org/10.30635/2415-0142.2

http://hdl.handle.net/10138/293619

https://doi.org/10.30635/2415-0142.2018.04.3

cc_by_nc

publishedVersion

Downloaded from Helda, University of Helsinki institutional repository.

This is an electronic reprint of the original article.

This reprint may differ from the original in pagination and typographic detail.

Please cite the original version. 


\title{
Evaluation of the Bioactivity of Water Extracts from Dicotyledonous Crops on Model Weeds and Pathogens
}

\author{
Leticia Valenzuela ${ }^{1, *}$, Ling Zou ${ }^{1,2}$, Arja Santanen ${ }^{1}$ and Pirjo S. A. Mäkelä ${ }^{1}$ \\ ${ }^{1}$ Department of Agricultural Sciences, University of Helsinki, Finland; ${ }^{2}$ Yunnan Flower Research Institute, \\ Yunnan Academy of Agricultural Sciences, China
}

\begin{abstract}
The bioactivity of secondary metabolites from faba bean, white lupine, winter turnip rape, and caraway extracts was evaluated against the growth of the fungal pathogens Fusarium culmorum (W.G. Sm.) Sacc., Rhizoctonia solani J.G. Kühn, and Botrytis cinerea Pers., and the germination and growth of the weeds Elymus repens (L.) Gould and Arabidopsis thaliana (L.) Heynh. An agar diffusion assay was used on the fungal pathogens and a classic in vitro bioassay on the weeds. Extracts of white lupine and winter turnip rape reduced the colony growth of $R$. cinerea. Arabidopsis germination decreased and root malformation increased by all the extracts tested. Elymus repens germination was unaffected, yet the root elongation was reduced by the caraway, lupine, and winter turnip rape extracts.
\end{abstract}

Keywords: Arabidopsis, quackgrass, germination, root elongation, secondary metabolites.

\section{INTRODUCTION}

Numerous crops synthesize, as part of their defense systems, secondary metabolites that can be used in competition against weeds and pathogens. Most of these compounds are localized in different plant organs as active polar and nonpolar compounds [1]. 2008). Their synthesis and activity are dependent on the physiological stage of the plant [2]. These compounds are naturally released as leachates or root exudates [3] or through volatilization and tissue decomposition [4]. Some niche crops, such as faba bean (Vicia faba L.), white lupine (Lupinus albus L.), winter turnip rape (Brassica rapa L. ssp. oleifera (DC.) Metzg.), and caraway (Carum carvi L.) produce secondary metabolites that interfere with the germination and development of weeds and can control fungi $[5,6]$. Nonetheless, the effects of the secondary metabolites may be dependent on internal and external factors, such as target plant classification into monocotyledons or dicotyledons, the seed size, doses of metabolites, soil type, temperature, and soil microorganisms [7].

In Finland, quackgrass (Elymus repens (L.) Gould) is one of the most common weeds in agricultural land and accounts for most biomass accumulation in both conventional and organic farms of the country [8]. It is a highly competitive perennial weed that causes yield losses in temperate regions throughout the world. In Scandinavia, E. repens is mostly controlled with herbicides, although organic agriculture tillage methods, e.g. deep plowing is used to control perennial weeds [9].

"Address correspondence to this author at the Department of Agricultural Sciences, PO Box 223, 00014 University of Helsinki, Finland;

E-mail: leticia.valenzuela@helsinki.fi
In Finland, in addition to weed infestation, the fungal pathogens Fusarium culmorum (W.G. Sm.) Sacc., Rhizoctonia solani J.G. Kühn (teleomorph: Thanatephorus cucumeris (A.B. Frank) Donk), and Botrytis cinerea Pers. regularly cause yield losses in major crops such as wheat (Triticum aestivum L.), rye (Secale cereale L.), barley (Hordeum vulgare L.), oat (Avena sativa L.), and potato (Solanum tuberosum L.) [10]. Fusarium contamination accounted for 2 to $25 \%$ in naturally infected samples of spring wheat, and $F$. culmorum was among the most common species found [11]. Rhizoctonia solani is the principal pathogen affecting potato production, causing canker [12]. Botrytis cinerea can attack more than 200 host plant species including mustards (Brassica L.), causing gray mold disease [13].

In the present investigation, the bioactivity of extracts prepared from the shoots, roots, and whole plants of faba bean, white lupine, winter turnip rape, and caraway was evaluated against the growth and germination of the model weeds, the dicotyledonous thale cress (Arabidopsis thaliana (L.) Heynh.) and monocotyledonous $E$. repens. The bioactivity of these extracts was also evaluated against the growth of fungal pathogens $F$. culmorum, $R$. solani, and $B$. cinerea.

\section{MATERIALS AND METHODS}

\subsection{Extract Preparation}

Caraway (cv. Sylvia), turnip rape (cv. Kulta), faba bean (cv. Kontu), and white lupine (cv. Vesna) were grown in 10-I pots containing a commercial fertilized potting mix (Karkea ruukutusseos WR8014; Kekkilä Oy, Vantaa, Finland). In each pot, 30 seeds of each 
species were sown, and the potting mix was saturated with water. The pots were placed in a greenhouse with day/night temperatures of 22 to $18{ }^{\circ} \mathrm{C}$ and relative humidity of about $40 \%$. High-pressure sodium lamps (E40 400W; Osram GmbH, Munich, Germany) provided an 18-h photoperiod with a photosynthetic photon flux density (PPFD) of $340 \mu \mathrm{mol} \mathrm{m} \mathrm{m}^{-2} \mathrm{~s}^{-1}$ throughout the day at the top of the canopy.

At flowering, the plants were harvested. One third of the plants were treated as whole (shoots and roots), whereas the rest were divided into shoots or roots. The roots were washed to remove soil. A 300-g subsample of the harvested plant material was cut into a $200-\mathrm{ml}$ jar (Sigma-Aldrich Corp., St. Louis, MO, USA), and $150 \mathrm{ml}$ of sterile water were added to extract the polar metabolites. The samples were shaken at 80 revolutions per minute (rpm) for $20 \mathrm{~h}$. The extract was filter-sterilized with a vacuum filtration system (polyethersulfone (PES) $0.45 \mu \mathrm{m}$ per $250 \mathrm{ml}$; VWR International, Radnor, PA, USA) and freeze-dried. A $100-\mathrm{mg}$ subsample was diluted into $50 \mathrm{ml}$ of Milli-Q (MQ) sterile ultrapure water (Millipore Corp., Burlington, MA, USA) and stored at $4{ }^{\circ} \mathrm{C}$ until further use.

Before use, the $\mathrm{pH}$ and electrical conductivity of the stock extract were measured (Jenway 4020; Jenway, Stone, Staffordshire, UK) at $25^{\circ} \mathrm{C}$. The $\mathrm{pH}$ values of the caraway and white lupine extracts were alkaline (7.2 to 8.6), whereas the turnip rape and faba bean extracts were acidic (5.2 to 6.7), except for the faba bean whole-plant extract $(\mathrm{pH}$ 7.1). The electrical conductivity of all extracts varied from 3.5 to 9.6 $\mathrm{mS} \mathrm{m}^{-1}$ (data not shown).

\subsection{Bioassay of Model Fungal Pathogens}

Each extract was tested on the three fungal pathogens: B. cinerea, F. culmorum, and R. solani, following the standard procedure of the agar diffusion assay [14]. An agar disk was cut to create a well in the center of the medium where the fungal solution was deposited. Additionally, four equidistant wells were also cut and $0.1 \mathrm{ml}$ of the extract was added to each well. As a positive control, prochloraz-imidazole $\left(450 \mathrm{~g} \mathrm{I}^{-1}\right.$, Sportak; Bayer CropScience, Bayer AG, Leverkusen, Germany) was diluted to $1: 10(\mathrm{v} / \mathrm{v})$ and added instead of the extracts. Sterile $M Q$ water was used as the negative control. The Petri dishes were sealed with parafilm and incubated at $22{ }^{\circ} \mathrm{C}$ in alternating $12-\mathrm{h}$ light/dark periods. After $3 \mathrm{~d}$, two perpendicular diameters of the fungal colony were measured in each dish to obtain the mean value. The experiment was completely randomized with four replicates of each treatment.

\subsection{Bioassay of Model Weeds}

The E. repens seeds were collected at the Viikki Experimental Farm $\left(60^{\circ} 22^{\prime} \mathrm{N}, 25^{\circ} 03^{\prime} \mathrm{E}\right)$, University of Helsinki, Finland. The seeds were cold-treated at -20 ${ }^{\circ} \mathrm{C}$ for $48 \mathrm{~h}$, followed by surface sterilization in $1.5 \%$ sodium hypochlorite and rinsed six times with sterile distilled water. The sterile seeds were placed on $0.8 \%$ water agar (Sigma-Aldrich) in Petri dishes $(\varnothing 9 \mathrm{~cm})$. In each dish, $3 \mathrm{ml}$ of either sterile water or plant extract was added. The experiment was completely randomized with five replicates of each treatment. All the dishes were sealed with parafilm and placed in a growth cabinet with day/night temperatures of $25 / 20^{\circ} \mathrm{C}$ and relative humidity of about $30 \%$. Natural white lamps (L36W/76; Osram) provided an 18-h photoperiod with PPFD of $140 \mu \mathrm{mol} \mathrm{m} \mathrm{m}^{-2} \mathrm{~s}^{-1}$. After $15 \mathrm{~d}$, the percentage of germination was evaluated and the root length was measured (only for the most efficient extracts).

Arabidopsis thaliana, ecotype Columbia, seeds were surface-sterilized in $70 \%$ ethanol for $2 \mathrm{~min}$, followed by treatment in $1.5 \%$ sodium hypochlorite containing $20 \mu \mathrm{l}$ of Tween-80 (Sigma-Aldrich) for 10 min and rinsed six times with sterile distilled water. Murashige-Skoog (MS) medium (Duchefa Biochemie, Haarlem, The Netherlands) was solidified with $0.8 \%$ agar (Sigma-Aldrich), and before solidification $3 \mathrm{ml}$ of extract were mixed with $50 \mathrm{ml}$ of medium. Ten seeds were sown in the medium. The experiment was completely randomized with five replicates of each treatment. The Petri dishes were sealed and placed at $4{ }^{\circ} \mathrm{C}$ in darkness for $72 \mathrm{~h}$, after which they were placed in a growth cabinet under the same growing conditions as the E. repens. The root and shoot morphology of the 7-d-old seedlings was viewed under a dissecting microscope (Leica MZ FLIII; Leica Microsystems, Wetzlar, Germany) with an attached CCD camera. After $14 \mathrm{~d}$, the percentage of germination was recorded.

\subsection{Data Analysis}

The effect of extracts on the seed germination and growth of the colony size of the pathogens was assessed with a one-way analysis of variance (ANOVA) (PASW version 22.0, IBM Corp., Armonk, NY, USA). In the analysis, each plant extract was considered as a separate treatment. The normal 


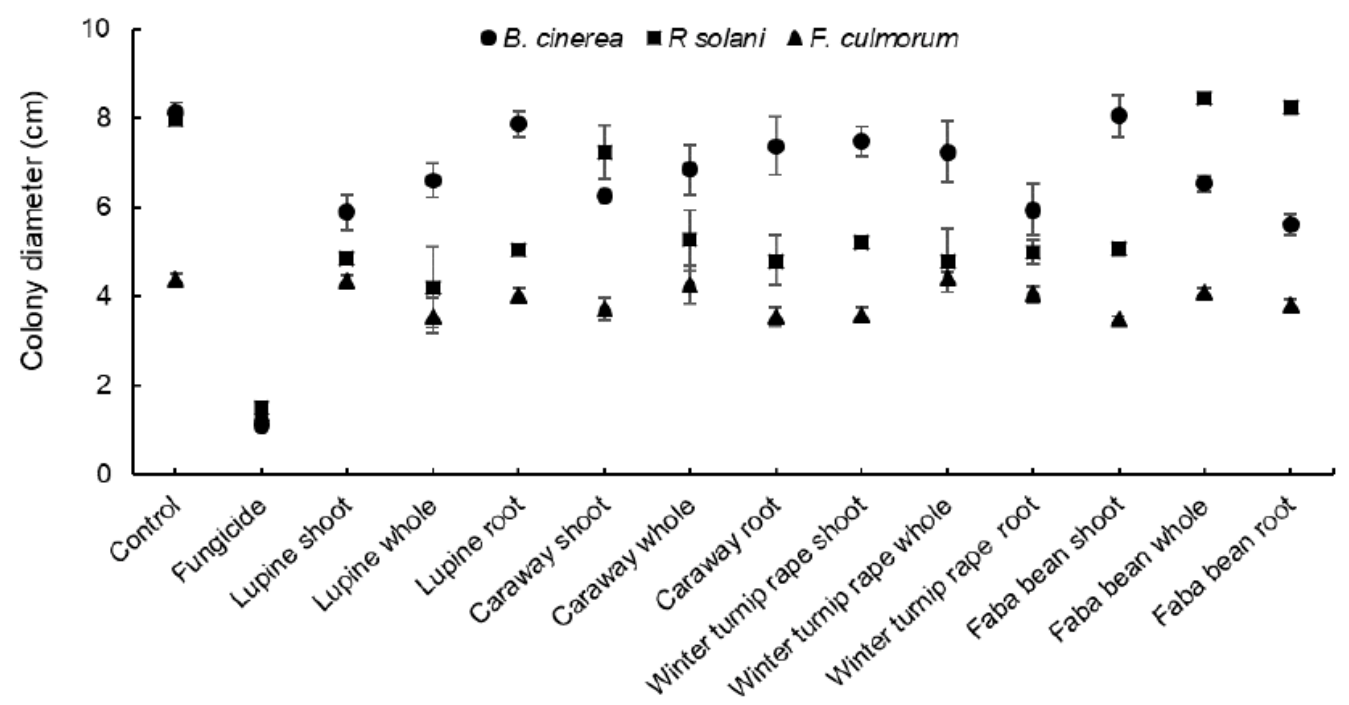

Figure 1: Colony diameter (cm) of Rhizoctonia solani, Fusarium culmorum, and Botrytis cinerea measured $3 \mathrm{~d}$ after treatment with plant extracts. Data shown are means $\pm S E, n=4$.

distribution was tested but since the transformations did not improve the normality, the distribution was assumed normal. A Tukey post-hoc test was utilized to compare the means of the treatments $(p<0.05)$.

\section{RESULTS AND DISCUSSION}

\subsection{Pathogen Bioassays}

The results from the pathogen bioassay indicated that the plant extracts affected the fungal species differently. The extracts tested caused an approximately 7- to 8-fold decrease in the colony growth of $B$. cinerea and $R$. solani, whereas the colony growth of $F$. culmorum was not affected by the extracts (Figure 1). However, the response of the $B$. cinerea colonies varied among the extracts tested. The only effective extracts studied against $R$. cinerea were lupine shoot, winter turnip rape root, and faba bean root. Rhizoctonia solani was the most sensitive to the plant extracts studied. All the extracts from white lupine and winter turnip rape decreased the diameter of the $R$. solani colonies by $3 \mathrm{~cm}$ in comparison to the control. Similar effects were observed in the colonies treated with caraway root and whole-plant extracts. In contrast, the colonies treated with faba bean root and wholeplant extracts grew larger than the untreated controls. However, the faba bean shoot extract markedly reduced the colony size of $R$. solani.

Although the active compounds of the extracts were not identified in this investigation, the effectiveness of lupine shoot extract may have been related to its alkaloid content, specifically to quinolizidine alkaloids. The antifungal mechanisms of alkaloids are based on their ability to simultaneously affect several organelles and biochemical pathways in cells, e.g. the pathway controlling calcium phosphate regulation. The impaired pathway leads to an increment of reactive oxygen species (ROS) and to dysfunctional mitochondria, inducing cell death [15].

The most active secondary metabolites reported to interfere with pathogen growth in Brassica are glucosinolates. These compounds are not active until their hydrolysis by the enzyme myrosinate, after which the glucosinolates are transformed into isothiocyanates [16]. Our observations are in accordance with those of McCully et al. [17] who reported that the concentration of glucosinolates in oilseed rape (Brassica napus L.) was 5 -fold larger in roots than in shoots. This may explain the effectiveness of the winter turnip rape root extracts in suppressing the colony growth of $B$. cinerea and $R$. solani. Additionally, $R$. solani is known to be sensitive to aliphatic isothiocyanates, due to the solubility of these compounds [18].

The active compounds in faba bean extracts are presumably flavonoids and tannins. Previously, Elad [19] reported that $1.7 \mathrm{~g} \mathrm{~L}^{-1}$ of tannic acid was sufficient to reduce the growth of $B$. cinerea). Similarly, Castillo et al. [20] reported that $1 \mathrm{~g} \mathrm{~L}^{-1}$ of total tannins completely inhibited $R$. solani growth. The effect of caraway root extracts against $R$. solani may be linked 
to the content of aldehydes [21], the active mechanism of which was previously associated with disruption of the permeability of the cell membranes [22].

\subsection{Weed Bioassays}

The germination percentage of $E$. repens seeds was not affected by the plant extracts tested (Figure 2). Nonetheless, its primary root was approximately $85 \%$ shorter following treatment with caraway shoot and whole-plant extracts, $70 \%$ shorter following treatment with lupine whole-plant extract, and $57 \%$ shorter following treatment with lupine shoot extract than in untreated controls (Figure 3). However, in this investigation, the major effect from the extracts was observed in root growth, thus most likely reducing the competitiveness of the weed in plant stands.

In contrast to $E$. repens, the germination of $A$. thaliana seeds was significantly inhibited by all the extracts tested (Figure 2). Furthermore, all the extracts tested caused stunted shoot growth and malformations in the roots of $A$. thaliana (Figure 4). The abnormalities observed were mostly bifurcation of the primary root, excessive numbers of secondary roots, and underdevelopment of the root system. These effects were most clear following treatment with winter turnip rape shoot and whole-plant extracts. However,

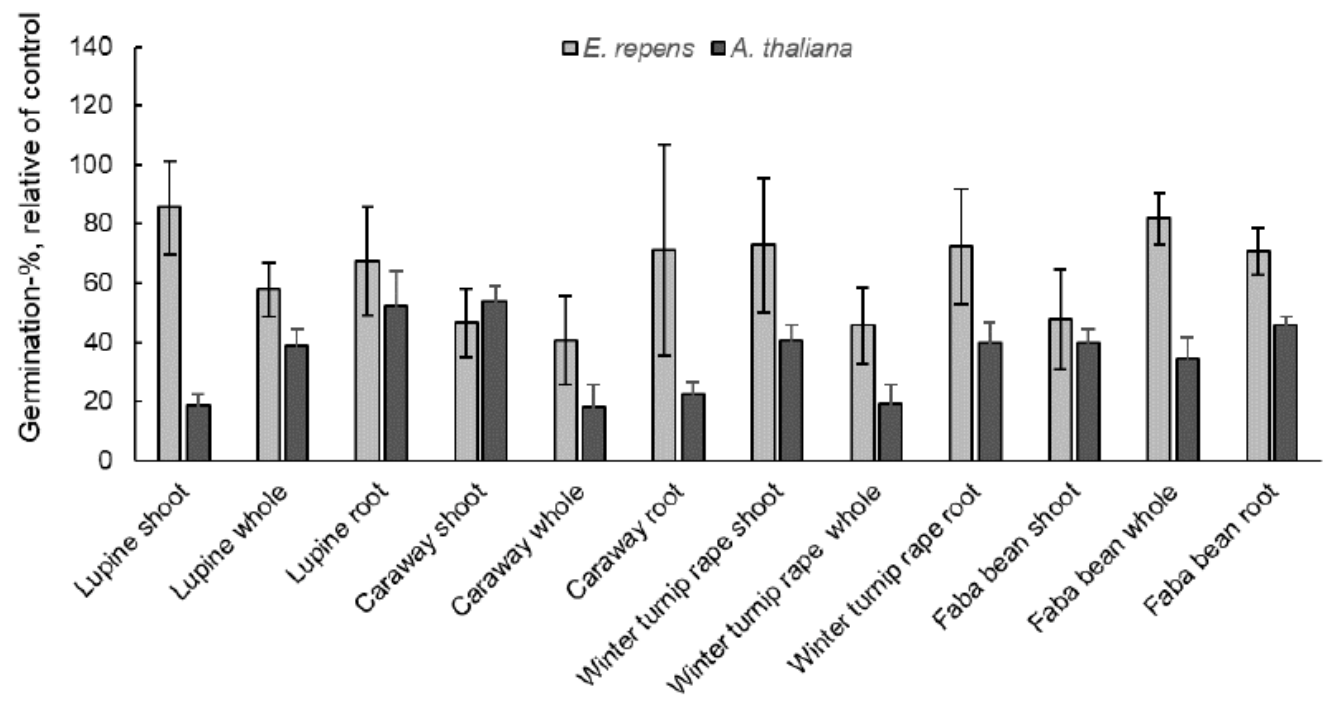

Figure 2: Germination percentage shown as relative values to untreated control evaluated $14 \mathrm{~d}$ after seeding in Elymus repens and Arabidopsis thaliana, following treatment with the plant extracts. Data shown are means $\pm \mathrm{SE}, \mathrm{n}=5$.

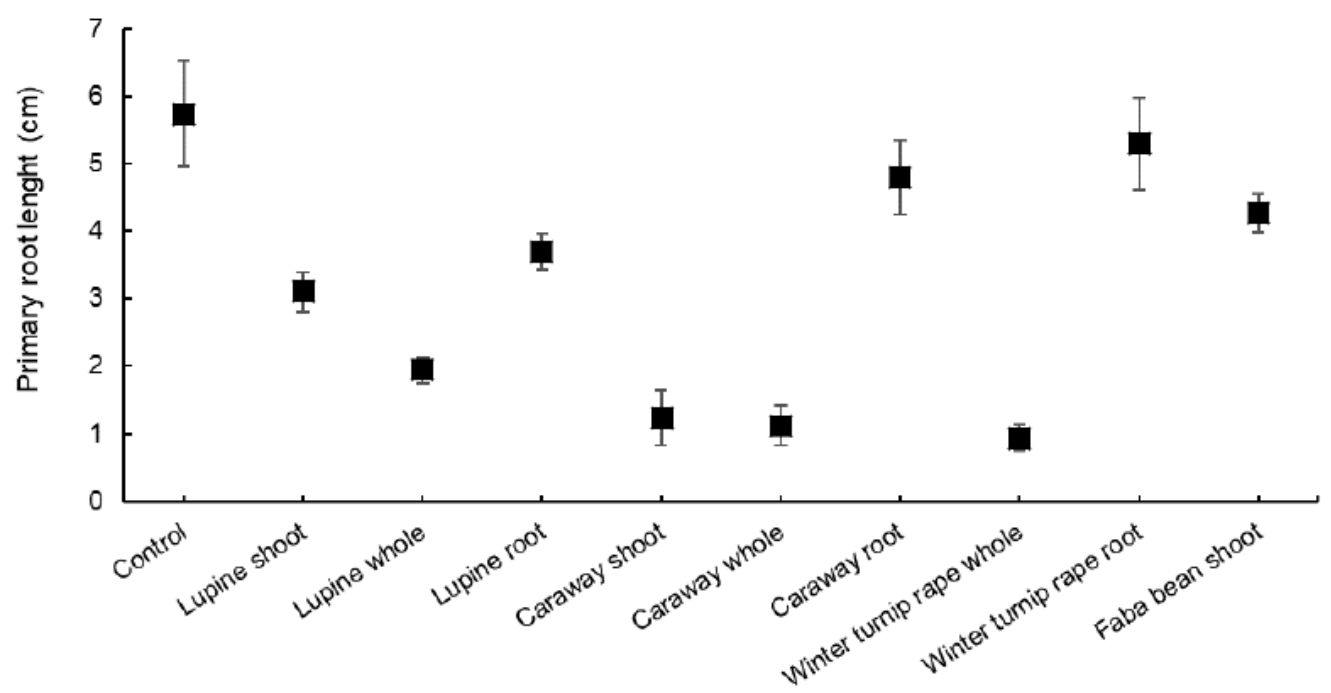

Figure 3: Length of the primary root of Elymus repens when measured $14 \mathrm{~d}$ after the beginning of the treatment. The most effective extracts are shown, including the control. Data shown are means $\pm S E, n=5$. 

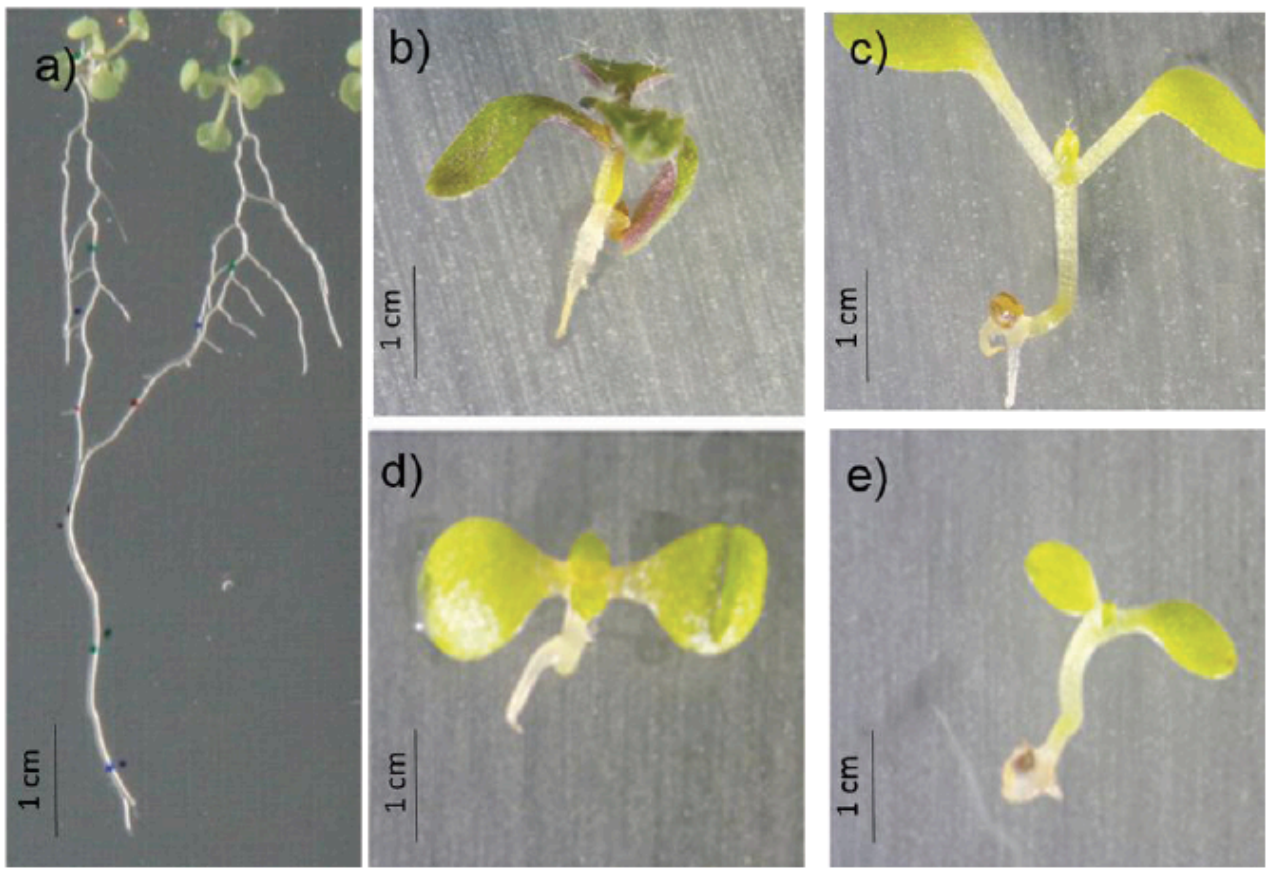

Figure 4: Primary root of Arabidopsis thaliana $14 \mathrm{~d}$ after treatment with plant extracts: a) control, b) faba bean root extract, c) winter turnip rape shoot extract, d) caraway whole-plant extract, and e) white lupine whole-plant extract.

treatment with winter turnip rape extracts also increased the growth of $A$. thaliana shoots (Figure 4).

The secondary metabolites in the extracts were not identified, but based on previous investigations, carvacrol, limonene, carvone, and carveol in caraway inhibit germination of common weed species, such as wild radish (Raphanus raphanistrum L.), charlock mustard (Sinapis arvensis L.), and common sowthistle (Sonchus oleraceus L.) [23]. Limonene for example, reduces the respiratory activity of the mitochondria apparently by disturbing the ATP synthase and reducing the ATP production [24]. Lupine alkaloids (mainly lupanine, sparteine, and quinidine) inhibit germination of garden lettuce (Lactuca sativa L.) and gardencress pepperweed (Lepidium sativum L.) seeds [25]. Alkaloids might have multiple target points, but for example, quinidine has its major effect in the $\mathrm{Na}^{+}$and $\mathrm{K}+$ channels. These membrane proteins play important role in enzyme activation and the stabilization of protein synthesis [26]. Glucosinolates as isothiocyanates interfere with the development of seedlings through disruption of the auxin balance in plants [27].

\section{CONCLUSIONS}

In conclusion, the fungi and weed species examined responded differently to the extracts tested. Fusarium culmorum responded to none of the extracts tested, whereas $R$. solani was affected by all winter turnip rape and white lupine extracts, as well as caraway root and whole-plant extracts. The colony growth of $B$. cinerea was reduced following treatment with lupine shoot, winter turnip rape root, and faba bean root extracts. Arabidopsis thaliana germination and root growth responded to all the extracts tested, whereas $E$. repens root growth was only affected by the caraway, lupine, and winter turnip rape extracts. Although the specific secondary metabolites in the extracts remain unidentified, the results of this study indicate a need for further investigation of the feasibility of using plant extracts in weed and pathogen management.

\section{ACKNOWLEDGEMENTS}

We thank the Maj and Tor Nessling Foundation, Olvi Foundation, and Niemi-Säätiö for funding. We are grateful to Dr. Hilkka Koponen for providing the fungal pathogens and Dr. Aleksandar Mikić, Novi Sad Seme, Serbia for providing the seeds of white lupine. We also express our gratitude to Markku Tykkyläinen, Axel Baarman, and Ville Pursiainen for technical assistance.

\section{REFERENCES}

[1] Figueiredo AC, Barroso JG, Pedro LG and Scheffer JJC. Factors affecting secondary metabolite production in plants: volatile components and essential oils. Flavour and Fragrance Journal 2008; 23: 213-226. https://doi.org/10.1002/ffj.1875

[2] Cirak C, Radusiene $\mathrm{J}$ and Camass N. Pseudohypericin and hyperforin in two Turkish Hypericum species: Variation among plant parts and phenological stages. Biochemical Systematics and Ecology 2008; 36: 377-382. https://doi.org/10.1016/j.bse.2007.12.009 
[3] Cheng $F$ and Cheng $Z$. Research progress on the use of plant allelopathy in agriculture and the physiological and ecological mechanism of allelopathy. Frontiers in Plant Science 2015. DOI:10.3389/fpls.2015.01020 https://doi.org/10.3389/fpls.2015.01020

[4] Vaughn SF and Boydston RA. Volatile allelochemicals released by crucifer green manures. Journal of Chemical Ecology 1997; 23: 2107-2116. https://doi.org/10.1023/B:JOEC.0000006432.28041.82

[5] Asaduzzaman M and Asao T. Autotoxicity in beans and their allelochemicals. Scientia Horticulturae 2012; 134: 26-31. https://doi.org/10.1016/j.scienta.2011.11.035

[6] Zou L, Santanen A, Tein B, Stoddard FL and Mäkelä PSA. Interference potential of buckwheat, faba bean, oilseed hemp, vetch, white lupine and caraway to control couch grass weed. Allelopathy Journal 2014; 33: 227-236

[7] Macías F, Castellano D and Molinillo JMG. Search for a standard phytotoxic bioassay for allelochemicals. Selection of standard target species. Journal of Agriculture and Food Chemistry 2000; 48: 2512-2521. https://doi.org/10.1021/jf9903051

[8] Salonen J, Hyvönen $T$ and Jalli $H$. Weeds in spring cereal fields in Finland - A third survey. Agriculture and Food Science in Finland 2001; 10: 347-364. https://doi.org/10.23986/afsci.5705

[9] Brandsæter LO, Bakken AK, Mangerud K, Riley H, Eltun R and Fykse $H$. Effects of tractor weight, wheel placement and depth of ploughing on the infestation with perennial weeds in organic farmed cereals. European Journal of Agronomy 2011; 34: 239-246. https://doi.org/10.1016/j.eja.2011.02.001

[10] Natural Resources Institute Finland. Crop production statistics and the quality of the grain harvest 2015. Crop Production Statistics. Available on the Internet 2016: http://www.maataloustilastot.fi/en/tilasto/175

[11] Jestoi M, Rokka M, Yli-Mattila T, Parikka P, Rizzo A and Peltonen K. The presence and concentrations of the Fusarium-related mycotoxins beauvericin, enniatins and moniliformin in Finnish grain samples. Food Additives and Contaminants 2004; 21: 794-802. https://doi.org/10.1080/02652030410001713906

[12] Banville GJ. Yield losses and damage to potato plants caused by Rhizoctonia solani Kuhn. American Journal of Potato Research 1989; 66: 821-834. https://doi.org/10.1007/BF02853963

[13] Williamson B, Tudzynski B, Tudzynski $P$ and van Kan JAL. Botrytis cinerea: the cause of grey mould disease. Molecular Plant Pathology 2007; 8: 561-580. https://doi.org/10.1111/j.1364-3703.2007.00417.x

[14] Yu GY, Sinclair JB, Hartman GL and Bertagnolli BL. Production of iturin $A$ by Bacillus amyloliquefaciens suppressing Rhizoctonia solani. Soil Biology and Biochemistry 2002; 34: 955-963. https://doi.org/10.1016/S0038-0717(02)00027-5

[15] Khan MK, Karnpanit W, Nasar-Abbas SM, Huma Z and Jayasena V. Phytochemical composition and bioactivities of lupin: A review 2015. DOI: 10.1111/ijfs.12796

https://doi.org/10.1111/ijfs.12796

[16] Brown PD and Morra MJ. Hydrolysis products of glucosinolates in Brassica napus tissues as inhibitors of seed germination. Plant and Soil 1996; 181: 307-316.

\section{https://doi.org/10.1007/BF00012065}

[17] McCully ME, Miller C, Sprague SJ, Xuang CX and Kirkegaard JA. Distribution of glucosinolates and sulphur rich cells in roots of field-grown canola (Brassica napus). New Phytologist 2008; 180: 193-205. https://doi.org/10.1111/j.1469-8137.2008.02520.x

[18] Sarwar M, Kirkegaard JA, Wong PTW and Desmarchelier JM. Biofumigation potential of brassicas. III. In vitro toxicity of isothiocyanates to soil-borne fungal pathogens. Plant and Soil 1998; 201: 103-112. https://doi.org/10.1023/A:1004381129991

[19] Elad $Y$. The use of antioxidants (free radical scavengers) to control grey mould (Botrytis cinerea) and white mould (Sclerotinia sclerotionum) in various crops. Plant Pathology 1992; 41: 417-426. https://doi.org/10.1111/j.1365-3059.1992.tb02436.x

[20] Castillo F, Hernández D, Gallegos G, Mendez M, Rodríguez $\mathrm{R}$, et al. In vitro antifungal activity of plant extracts obtained with alternative organic solvents against Rhizoctonia solani Kühn. Industrial Crops and Products 2010; 32: 324-328. https://doi.org/10.1016/j.indcrop.2010.05.013

[21] Wichtmann EM and Stahl-Biskup E. Composition of the essential oils from caraway herb and root. Flavour and Fragance Journal 1987; 2: 83-89. https://doi.org/10.1002/ffj.2730020207

[22] Hyldgaard M, Mygind T and Meyer RL. Essential oils in food preservation: mode of action, synergies, and interactions with food matrix components. Frontiers in Microbiology 2012; 3 : 12. http://doi.org/10.3389/fmicb.2012.00012 https://doi.org/10.3389/fmicb.2012.00012

[23] Azirak S and Karaman S. Allelopathic effect of some essential oils and components on germination of weed species. Acta Agriculturae Scandinavica - Soil \& Plant Science 2008; 58: 88-92. https://doi.org/10.1080/09064710701228353

[24] Weir TL, Park SW and Vivanco JM. Biochemical and physiological mechanisms mediated by allelochemicals. Current Opinion in Plant Biology 2004; 4: 472-479. https://doi.org/10.1016/j.pbi.2004.05.007

[25] Wink M. Inhibition of seed germination by quinolizidine alkaloids - Aspects of allelopathy in Lupinus albus L. Planta 1983; 158: 365-368. https://doi.org/10.1007/BF00397339

[26] Dreyer I and Uozumi N. Potassium channels in plant cells FEBS Journal 2011; 278: 4293-4303. https://doi.org/10.1111/j.1742-4658.2011.08371.x

[27] Chen S, Petersen BL, Olsen CE, Schulz A and Halkier BA. Long-distance phloem transport of glucosinolates in Arabidopsis. Plant Physiology 2001; 127: 194-201. https://doi.org/10.1104/pp.127.1.194

(C) 2018 Leticia, et al.; Licensee Journal of Agriculture Food and Development.

This is an open access article licensed under the terms of the Creative Commons Attribution Non-Commercial License (http://creativecommons.org/licenses/by-nc/3.0/), which permits unrestricted, non-commercial use, distribution and reproduction in any medium, provided the work is properly cited. 